\title{
Bladder augmentation in children: current problems and experimental strategies for reconstruction
}

\author{
Sophie Langer · Christine Radtke · Eva Györi · Alexander Springer · Martin L. Metzelder
}

Received: 29 January 2018 / Accepted: 21 June 2018 / Published online: 6 August 2018

(C) The Author(s) 2018

\begin{abstract}
Summary Bladder augmentation is a demanding surgical procedure and exclusively offered for selected children and has only a small spectrum of indications. Paediatric bladder voiding dysfunction occurs either on a basis of neurological dysfunction caused by congenital neural tube defects or on a basis of rare congenital anatomic malformations. Neurogenic bladder dysfunction often responds well to a combination of specific drugs and/or intermittent self-catheterization. However, selected patients with spinal dysraphism and children with congenital malformations like bladder exstrophy and resulting small bladder capacity might require bladder augmentation. Ileocystoplasty is the preferred method of bladder augmentation to date. Because of the substantial long-and short-term morbidity of augmentation cystoplasty, recent studies have tried to incorporate new techniques and technologies, such as the use of biomaterials to overcome or reduce the adverse effects. In this regard, homografts and allografts have been implemented in bladder augmentation with varying results, but recent studies have shown promising data in terms of proliferation of urothelium and muscle cells by using biological silk grafts.
\end{abstract}

\footnotetext{
S. Langer · A. Springer $\cdot$ M. L. Metzelder $(\bowtie)$

General Hospital Vienna, Clinical Department of Paediatric

Surgery, Medical University of Vienna, Waehringer

Guertel 18-20, 1090 Vienna, Austria

martin.metzelder@meduniwien.ac.at

C. Radtke · E. Györi

General Hospital Vienna, Clinical Department of Plastic and

Reconstructive Surgery, Medical University of Vienna,

Waehringer Guertel 18-20, 1090 Vienna, Austria
}

Keywords Urinary bladder dysfunction - Neurogenic bladder · Bladder augmentation · Ileocystoplasty · Biomaterials

\section{Blasenaugmentation im Kindesalter: derzeitiges Komplikationsprofil und mögliche experimentelle Lösungsansätze}

Zusammenfassung Die Harnblasenaugmentation ist eine anspruchsvolle chirurgische Operation, die betroffenen Kindern unter bestimmten Voraussetzungen vorbehalten ist. Die kindliche Harnblasenentleerungsstörung basiert überwiegend auf angeborenen Neuralrohrdefekten und seltener auf angeborenen Defekten mit fehlentwickelter Harnblase. Die Dysfunktion bei neurogener Blase ist sowohl gut medikamentös als auch mit der sog. intermittierenden Selbstkatheterisierung behandelbar. Jedoch kann die Blasenaugmentation für ausgewählte Patienten mit spinaler Dysraphie und Kinder mit angeborenen Fehlbildungen wie Blasenekstrophie zur Vergrößerung der Blasenkapazität erforderlich sein. Die derzeitig am häufigsten verwendete Ileozystoplastie hat erhebliche unerwünschte postoperative Nebeneffekte. Zur Reduzierung dieser substanziellen Lang- und Kurzzeit-Komorbiditäten wird derzeit an neuen Techniken unter Verwendung von Homografts und Allografts geforscht, wobei aktuell auch zunehmend die Verwendung von Biomaterialien wie biologischen Transplantaten aus Seide untersucht wird, die eine Einsprossung von körpereigenem Urothel und Muskelzellen erlauben könnten.

Schlüsselwörter Harnblasendysfunktion · Neurogene Harnblase · Blasenaugmentation - Ileozystoplastie · Biomaterialien 
Abbreviations

CIC Clean intermittent self-catheterization

MRI Magnetic resonance imaging

SIS Small intestinal submucosa

\section{Introduction}

Loss or malfunction of the lower urinary tract may cause urinary incontinence and chronic renal failure. The most common underlying conditions are spinal dysraphism (spina bifida), congenital malformations (exstrophy-epispadias complex, cloacal malformations) and trauma. Modern treatment of lower urinary tract dysfunctions consists of clean intermittent catheterization (as proposed by Lapides in 1972 [1]), medical treatment (anticholinergic medication and botulinum toxin A [2, 3]) and surgical reconstruction (augmentation cystoplasty, creation of a catheterizable conduit $[4,5])$.

In this article we review various conditions and surgical options, and highlight new concepts for the use of biomaterials and tissue engineering in the field of urinary bladder reconstruction.

\section{Clinical presentation and issues}

\section{Neuropathic bladder}

Neural tube defects represent one of the most common birth defects (33-52/100,000 live births [6, 7]) as well as the most common cause of neurogenic bladder dysfunction [8]. In this regard, there is high accuracy and precision for obtaining the diagnosis by antenatal ultrasound [9].

Clinical presentation of neuropathic bladder includes incontinence, recurrent urinary tract infection and, if left untreated, chronic renal failure and endstage renal disease [10]. Bladder dysfunction is caused by detrusor and/or sphincter over- and underactivity (detrusor sphincter dyssynergy). A high-pressure and low-compliance bladder causes destruction of the bladder architecture, leading to diverticulation and loss of contractility, subsequently to vesicoureteral reflux, chronic renal failure and incontinence $[10,11]$.

\section{Congenital malformations}

Several rare anatomic malformations of the urogenital tract can cause bladder dysfunction as well, and are often diagnosed via prenatal ultrasound or magnetic resonance imaging (MRI) [12, 13]. Urogenital malformations that might require bladder augmentation include cloacal exstrophy $(\sim 0.19 / 100,000$ live births $[14,15])$ and bladder exstrophy $(\sim 3.3 / 100,000$ live births [12]). In both entities, the volume of the urinary bladder is compromised, as is the compliance of the bladder wall. Again, insufficient treatment can lead to renal impairment [13].

\section{Therapeutic options}

Modern treatment of lower urinary tract dysfunctions consists of

- Clean intermittent catheterization (CIC)

- Medical treatment (anticholinergic medication and botulinum toxin A)

- Surgical reconstruction

\section{Clean intermittent catheterization}

Clean intermittent self-catheterization (CIC) was introduced in 1972 and revolutionized the treatment of bladder dysfunction [1, 16]. CIC effectively lowers the intravesical pressure, provides urinary continence and consequently acts as protection against renal failure. It is the baseline treatment of bladder dysfunction and is also used in children with malformations of the exstrophy complex in addition to surgical management [17].

\section{Pharmacological non-surgical treatment}

Anticholinergic oral medication (i.e. oxybutynin) and muscle relaxation drugs in combination with intermittent self-catheterization poses an excellent option for long-term treatment in cases with neurogenic bladder dysfunction [18-20]. Side effects of the medical treatment include anticholinergic symptoms like drowsiness, flushes and palpitations. Additionally, a high compliance is needed, but in $75-90 \%[2,20]$ of all patients with neurogenic bladder dysfunction, this nonsurgical treatment shows good results. In case of persistent high intravesical pressure, submucosal injection of botulinum toxin A is implemented [21, 22].

\section{Surgical treatment}

Bladder augmentation If medical treatment and/or interventional methods have failed, and high intravesical pressure and urinary incontinence or recurring urinary tract infections persist combined with present vesicoureteral reflux and impaired renal function, surgical treatment in terms of bladder augmentation is indicated [8, 23]. Urinary bladder augmentation-reconstruction includes and simplifies:

- Augmentation of the bladder capacity

- via enterocystoplasty

- or autoaugmentation

- treatment of incontinence

- catheterizable conduit (Mitrofanoff appendicovesicostomy)

The median age of children with neurogenic bladder dysfunction who undergo bladder augmentation is 12 years and more than half of these patients have spina bifida as the underlying disease [5]. In anatomical malformations, bladder augmentation is considered earlier than in children with neurogenic bladder dysfunction; the median age of those children is 6.4 years $[15,24]$. The success rate of bladder augmentation with regard to the increase in bladder ca- 
Fig. 1 Scheme (a) and intraoperative view (b) of lleocystoplasty. (Painting in a with Courtesy of Stephan Spitzer [http://www.spitzerillustration.com/], Stephan Spitzer@ all rights reserved)


Table 1 Complication profile in bladder augmentation using gastrointestinal tissue

\begin{tabular}{|l|l|}
\hline Complication & Incidence (\%) \\
\hline Bowel obstruction & $3.2-10.3$ \\
\hline Bladder calculi & $15-40$ \\
\hline Bladder perforation & $2-8.6$ \\
\hline Excessive mucous production & -100 \\
\hline Metabolic acidosis, metabolic deterioration & -100 \\
\hline Malignant transformation of bowel/tumour formation & $0.5-10$
\end{tabular}

pacity as well as reduced intravesical pressure is high. In addition, the progression or the occurrence of kidney dysfunction can be avoided. Nonetheless, bladder augmentation requires close monitoring and further treatment of incontinence, and, thus, creation of a catheterizable Mitrofanoff conduit by use of the appendix vermiformis or small bowel is often part of the augmentation procedure [13]. In this regard, a catherizable urinary stoma may be crucial in the upkeep of the patient's compliance to prevent shortand long-term complications such as mucous plugging and chronic renal disease [25].

Ileum is most commonly used to perform an augmentation cystoplasty (Fig. 1), followed by colon and stomach $[5,15]$. Complications include small bowel obstruction, haematuria-dysuria syndrome, and an increase of urothelial cell carcinoma $[5,26]$. In rare cases, the ureter can also be used for cystoplasty. However, ureteral dilatation with ipsilateral impaired renal function with no vesicoureteral reflux are prerequisites [5]. In even less cases, autoaugmentation (vesicomyectomy or vesicomyotomy) can be performed, but only in patients with a preoperative bladder volume of $75-80 \%$ compared to normal sized bladders of healthy individuals. Fibrosis and regrowth of the detrusor muscle with need for surgical revision have been described [5].

Although the incidence of short-and long-term complications is high, patients report a significant improvement in their quality of life [13].
Current risk factors and morbidity Current risk factors and morbidity associated with bladder augmentation by non-urothelial tissue are shown in Table 1 .

Exposing non-urothelial tissue to urine causes a complex of problems. Through the constant contact of intestinal mucosa with urine, the accumulation of nitrosamines and infections can lead to premalignant and malignant degeneration in the long-term with incidences of $1.2-10.3 \%$ [5, 27-33]. In a recent review, Husmann et al. suggested that the primary bladder dysfunction as opposed to the augmentation cystoplasty is responsible for the development of intravesical neoplasia [25]. Moreover, bladder calculi with $15-40 \%[5,34]$ as well as metabolic dysfunction with up to a $100 \%$ incidence rate can occur [34-36]. Enterocystoplasty (gastrocystoplasties and ileocystoplasties) increases the risk of small bowel obstruction with a rate up to a $3.2-10.3 \%[5,37,38]$. Bladder perforation rate ranges from 2 to $8.6 \%$ [5]; additionally, spontaneous bladder rupture can occur in $3 \%$ and is connected to poor catherization compliance [25]. Excessive mucous production seems to occur more frequently after colocystoplasties and less frequently after ileocystoplasties and gastrocystoplasties [34, 39, 40].

Renal scarring and chronic renal failure in patients who undergo augmentation cystoplasty poses a longterm complication that seems to be linked to incompliance with self-catherization as well as catherization per urethra [25].

The implementation of an urothelium-like tissue might avoid such short-and long-term adverse effects (Table 1). Moreover, a high level of elasticity, a good compliance to high and rapid changes of the affecting pressure would be essential requirements to the used tissue. In addition, the potential development of a malignant degeneration of the used tissue should be excluded. 
Table 2 Fascia and muscle grafts in experimental bladder augmentation

\begin{tabular}{l|l|l|l|l}
\hline Year & Author & Animal & Graft material & Adverse effect \\
\hline 1917 & Neuhof [41] & Dogs & Muscle fascia & - \\
\hline 1990 & Weingarten et al. [43] & Ferrets & Myoperitoneal pedicle flap & Bladder stones \\
\hline 2001 & Manzoni et al. [42] & Rats & Autoaugmentation and muscle flaps & Bladder stones, chronic inflammation \\
\hline
\end{tabular}

Table 3 Demucosalized intestinal tissue in experimental bladder augmentation

\begin{tabular}{|l|l|l|l|l|}
\hline Year & Author & Animal & Graft material & Adverse effect \\
\hline 1988 & Oesch et al. [44] & Rats & De-epithelialized coecum & Incomplete urothelial coverage \\
\hline 1990 & Motley et al. [45] & Calves & Sigmoid & Graft diverticulation, residual intestinal mucosa \\
\hline 1995 & Niku et al. [46] & Rabbits & Colon & Postoperative mortality, inflammation \\
\hline 1999 & $\begin{array}{l}\text { Clementson Kockum } \\
\text { et al. [47] }\end{array}$ & Piglets & De-epithelialized colon & Graft contraction, fibrosis, metaplasia \\
\hline 2011 & Burgu et al. [48] & Rats & Ileum, gastric tissue & Metabolic imbalances, bladder stones \\
\hline
\end{tabular}

Table 4 Various types of tissue used in experimental bladder augmentation

\begin{tabular}{|c|c|c|c|c|}
\hline Year & Author & Animal & Graft material & Adverse effect \\
\hline 2012 & Thangappan et al. [49] & Rats & De-epithelialized bladder wall grafts & Chronic inflammation, residual donor cells \\
\hline 2003 & Yamataka et al. [50] & Rats & Bladder wall grafts & $\begin{array}{l}\text { Two-step procedure and immunosuppres- } \\
\text { sants may be required }\end{array}$ \\
\hline 1998 & Ikeguchi et al. [51] & Pigs & Ureteral tissue & Megaureter required \\
\hline 1998 & Cranidis et al. [52] & Rabbits & $\begin{array}{l}\text { Human dura mater, de-epithelialized small } \\
\text { intestine and gastric tissue }\end{array}$ & $\begin{array}{l}\text { Residual intestinal mucosa, stomach perfora- } \\
\text { tion, graft contraction }\end{array}$ \\
\hline 2004 & Aslan et al. [53] & Rat & Pedicled gastric tissue & $\begin{array}{l}\text { Bladder stones, metaplasia, postoperative } \\
\text { mortality, scarring }\end{array}$ \\
\hline 2012, 2013 & Dapena et al. $[55,56]$ & Rat & Uterus & Fibrosis \\
\hline 2017 & Barski et al. [58] & Rat & Human amniotic membrane & No increase in capacity \\
\hline
\end{tabular}

Animal testing in experimental bladder augmentation

\section{Naturally derived biomaterials}

- Fascia and muscle grafts (Table 2)

Experimental bladder augmentation with muscle or muscle-backed flaps has been done as early as the beginning of the last century. In 1917, Neuhof performed bladder augmentation in dogs utilizing free fascia grafts [41]; details on the outcome are not available.

Several experimental animal studies have since been performed on muscle-backed peritoneum, as well as rectus abdominis muscle flaps in rats [42]. Weingarten et al. found an increase in bladder volume in dogs after myoperitoneocystoplasty [43]. Manzoni et al. performed augmentation cystoplasty in thirty rats using rectus abdominis grafts, but bladder stones, chronic inflammatory response at sutures sites as well as undesirable residual muscle contractility occurred [42].

- Demucosalized intestinal tissue (Table 3)

Since the 1980s, animal studies (rats, calves, rabbits and pigs) focussing on using demucosalized colonic tissue and small intestine have been performed. Weingarten et al. found increased bladder volumes as well as urothelial growth [43].

Oesch et al.. [44] performed augmentation cystoplasty using stripped coecum and reported urothelial growth in only approximately half of the test rats after 4 months [44]. Motley et al. described urothelial growth in 10 out of 11 calves after sigmoidocystoplasty, but residual intestinal mucosa and graft diverticulation occurred [45]. Niku et al. showed incomplete urothelial growth in rabbits after colocystoplasty, leading to postoperative demise of several test animals due to inflammation [46]. Clementson Kockum et al. stated that de-epithelialized colocystoplasty leads to graft contraction, fibrosis and metaplasia in a study done on 21 piglets [47].

Burgu et al. tried to overcome the side effects of ileocystoplasty by either adding gastric tissue or by performing reversed in situ ileocystoplasty in rats. There was no improvement in terms of metabolic imbalances and stone formation following gastroileocystoplasty and ileocystoplasty [48].

- Other autologous tissue (Table 4)

Thangappan et al. successfully performed augmentation cystoplasty in 12 rats using de-epithelialized bladder wall grafts, although chronic inflammation as well as residual donor urothelial cells were found [49].

Although augmentation with live-related-donor bladder grafts in rats showed promising results, transferring this particular two-step procedure to humans appeared difficult, as stated by Yamataka et al. [50]. 
Table 5 Seeded de-epithelialized intestinal tissue in experimental bladder augmentation

\begin{tabular}{|c|c|c|c|c|}
\hline Year & Author & Animal & Graft material & Adverse effect \\
\hline 2001 & $\begin{array}{l}\text { Blanco Bruned et al. } \\
\text { [59] }\end{array}$ & Rats & Seeded intestinal grafts & No increase in capacity \\
\hline 2005 & Hafez et al. [60] & Pigs & Seeded demucosalized colon & $\begin{array}{l}\text { No information on results with neuropathic } \\
\text { bladder cells }\end{array}$ \\
\hline 2015 & Hidas et al. [61] & Pigs & Seeded demucosalized colon & $\begin{array}{l}\text { No information on results with neuropathic } \\
\text { bladder cells }\end{array}$ \\
\hline 2004 & Fraser et al. [62] & Minipigs & Seeded de-epithelialized uterine tissue/colon & $\begin{array}{l}\text { Incomplete urothelial coverage, graft contrac- } \\
\text { tion, fibrosis }\end{array}$ \\
\hline 2011 & Turner et al. [63] & Pigs & De-epithelialized colon, urothelium sheets & Graft shrinkage \\
\hline
\end{tabular}

Ureterocystaugmentation was performed successfully in pigs, but only after iatrogenic creation of megaureters as reported by Ikeguchi et al. [51].

Human dura mater, stomach and de-epithelialized small intestine tissue were used in augmentation cystoplasty in rabbits performed by Cranidis et al. The grafts covered iatrogenic bladder diverticuli following dertrusorectomy. The best results were obtained by using small intestine, although remnant intestinal mucosa was described. Graft contraction as well as bladder stones and fibrosis occurred in the groups with use of de-epithelialized gastric tissue and dura mater [52].

To bypass risks and complications affiliated with gastric or intestinal resection, pedicled gastrocystoplasty was performed in a rodent model in 2004. Unfortunately, this method showed a number of side effects such as bladder calculi, metaplasia, passing of the test animal as well as scarring [53, 54].

Dapena et al. demonstrated that hysterocystoplasty entails less adverse effects in animal studies than conventional enterocystoplasties in terms of metabolic imbalances and bladder calculi. However, smooth muscle cells were found to be sparse and there was evidence of fibrosis leading to obstruction [55-57].

In a rat model, human amniotic membranes were successfully tested as hypoallergenic grafts, but the bladder capacity did not increase after application of amniotic membranes for augmentation because of the small size of the defect in the bladder wall and graft [58].

Cell-seeded biological grafts Studies investigating cell-seeded biological grafts are outlined in Table 5 .

Schaefer et al. succeeded in transferring urothelial cells to colon and gastric grafts in vitro. However, they did not perform augmentation cystoplasty in vivo [64].

No increase in postoperative bladder volume was found following intestinal grafts seeded with urothelium in rats as demonstrated by Blanco Bruned et al., which resulted in a high mortality rate of $63.3 \%$ [59].

Seeding colonic grafts with urothelial cells and smooth muscle cells with an aerosol spraying technique was developed in 2003 [65]. Two ensuing studies showed the effectiveness of this bladder augmentation method in terms of cell adhesion and confluent epithelial coverage, although smooth muscle cell growth occurred only after an additional adding of detrusor cells to the urothelial cells [60, 61]. Hafez et al. compared aerosol transfer of smooth muscle cells onto demucosalized colon grafts to conventional colocystoplasty and found complete urothelial coverage only in the animals that underwent the aerosol graft cystoplasty [60]. Hidas et al. showed similar results, with no fibrosis or inflammation in porcine cystoplasty using the aerosol transfer technique. However, Hidas et al. stated that further studies in animals with neuropathic bladder should be done, as the results in a neuropathic bladder population might deviate [61].

Incomplete urothelial covering of seeded de-epithelialized uterine tissue derived from minipigs was reported in an experimental cystoplasty study done by Fraser et al., as well as graft contraction and fibrosis in de-epithelialized colonic tissue. [62].

Turner et al. successfully combined urothelium sheets with de-epithelialized colon tissue in a porcine model, but described graft shrinkage [63].

\section{- Acellular matrix grafts (Table 6)}

Biomaterials such as acellular matrix grafts and bladder submucosa collagen matrix have been used successfully in animal trials because of their good biocompatibility [66]. However, acellular bladder matrix grafts do not promote the ingrowth of smooth muscle cells and there is therefore no structural integration. Postoperative urinoma and urinary tract infection can occur as well, and antigenicity cannot be precluded completely [67-70].

Kropp et al. described complete urothelial graft overgrowth in 22 rats after cystoplasty with porcinederived small intestinal submucosa (SIS); however, there were bladder calculi, leakage, inflammation and incomplete smooth muscle cell growth noticed [71].

Parshotam Kumar et al. reported on the evidence of fibrosis with SIS in augmentation cystoplasty in lambs [72].

Sharma et al. seeded stem cells unto de-epithelialized small intestine tissue and used the graft to perform augmentation cystoplasty in primates, show- 
Table 6 Acellular matrix grafts in experimental bladder augmentation

\begin{tabular}{|l|l|l|l|l|}
\hline Year & Author & Animal & Graft material & Adverse effect \\
\hline 1995 & Kropp et al. [71] & Rats & SIS & $\begin{array}{l}\text { Bladder stones, inflammation, leakage, inflammation, } \\
\text { incomplete smooths muscle cell growth }\end{array}$ \\
\hline 2010 & $\begin{array}{l}\text { Parshotam Kumar } \\
\text { et al. [72] }\end{array}$ & Sheep & SIS & Fibrosis \\
\hline 2011 & Sharma et al. [73] & Primates & Seeded SIS with stem cells & No increase in capacity \\
\hline 2014 & Talab et al. [74] & Rabbits & Smooth-muscle cell sheets & Fibrosis, no information on postoperative bladder capacity \\
\hline 2016 & Zhe et al. [75] & Rats & ACS-seeded acellular bladder grafts & Bladder stones, insufficient cell growth \\
\hline SIS small intestinal submucosa, ACS adipose-derived stem cells & \\
\hline
\end{tabular}

Table 7 Polymers, collagen grafts, glycosaminoglycans in experimental bladder augmentation

\begin{tabular}{|c|c|c|c|c|}
\hline Year & Author & Animal & Material & Adverse effect \\
\hline 2007 & Pattison et al. [79] & Rats & Polymer scaffolds & $\begin{array}{l}\text { Bladder leak, bladder stones postoperative mortality, slow } \\
\text { biodegradation, mechanical difficulties }\end{array}$ \\
\hline 2008 & Kwon et al. [80] & Dogs & Polymer scaffold & Chronic inflammation, rapid scaffold degradation \\
\hline 2010 & $\begin{array}{l}\text { Parshotam Kumar } \\
\text { et al. [72] }\end{array}$ & Lambs & $\begin{array}{l}\text { Collagen scaffolds (INTEGRA }{ }^{\circledR} \text { [INTEGRA } \\
\text { LIFE SCIENCE CORPORATION, Plainsboro, } \\
\text { New Jersey, USA], SURGISIS }{ }^{\circledR} \text { [COOK, } \\
\text { Spencer, Indiana, USA]) }\end{array}$ & Fibrosis, graft contraction \\
\hline 2013 & Zhou et al. [81] & Rabbits & Acellular bladder matric and growth factors & $\begin{array}{l}\text { Bladder stones, graft shrinkage/calcification/scarring, urinary } \\
\text { leakage }\end{array}$ \\
\hline 2016 & Vardar et al. [82] & - & Collagen-fibrin scaffold and IGF-1 & Possible outlet obstruction because of tissue hypertrophy \\
\hline 2017 & Leonhäuser et al. [83] & Minipigs & Unseeded and seeded collagen scaffolds & Inconsistent cell ingrowth, risk of leakage \\
\hline
\end{tabular}

ing urothelial and smooth muscle growth but no increase in postoperative bladder volume [73].

By managing to perform a bladder augmentation using only smooth-muscle cells sheets, Talab et al. showed that neovascularization and epithelialization can be achieved without the use of a scaffold. However, there was no testing regarding the postoperative bladder volume. [74].

Muscle cell migration could also be enhanced by seeding acellular bladder grafts with adipose-derived stem cells, as demonstrated by Zhe et al., although bladder calculi and insufficient smooth muscle cell growth occurred [75].

Smooth muscle cells harvested from neuropathic bladders showed similar results to matrices seeded with normal cells when seeded unto matrices in vitro and then transplanted in vivo [76, 77]. This adds a new perspective to the findings of Subramaniam et al., who found that urothelial cells harvested from patients with bladder dysfunction showed reduced proliferation and differentiation [78].

- Polymers, collagen grafts, glycosaminoglycans (Тable 7)

Nano-structured polymers have been tested since 2007, providing adequate surface properties for smooth muscle and urothelium proliferation. However, death as a consequence of bladder leak was reported as well as untimely biodegradation, sparse smooth muscle cell growth, fibrosis as well as no increase of the bladder capacity $[79,80]$. However, seeded polymer grafts did not show these adverse effects as shown by Kwon et al. [80]. Parshotam et al. found that augmentation cystoplasty using
INTEGRA $^{\circledR}$ (INTEGRA LIFE SCIENCE CORPORATION, Plainsboro, New Jersey, USA) collagen matrix showed better results than SURGISIS ${ }^{\circledR}(\mathrm{COOK}$, Spencer, Indiana, USA) collagen matrix or demucosalized enterocystoplasty in lambs. Mucous cysts as well as intestinal obstruction, fibrosis and graft shrinkage were described in the enterocystplasty as well as in the SURGISIS ${ }^{\circledR}$ (COOK, Spencer, Indiana, USA) groups [72].

Zhou et al. advanced the use of tissue-engineered grafts by applying vascular endothelial growth factor and platelet-derived growth factor onto bladder acellular matrices to enhance muscle and vascular ingrowth. While the bioactive factors did promote smooth muscle cell regeneration and neovascularization, urinary leakage and bladder stone formation occurred, as well as graft shrinkage, scarring and graft calcification [81].

Further experimentation by Vardar et al. on collagen-fibrin scaffolds showed improved urothelialization and smooth muscle cell growth by adding insulin-like growth factor. Nonetheless, there was hypertrophy of the constructed urothelium which could lead to outlet obstruction [82].

In a recent study from 2017, unseeded and seeded cystoplasty collagen grafts were compared, with inconsistent results regarding the ingrowth of urothelial and smooth muscle cells [83].

Synthetic materials Synthetic materials which have been employed in experimental bladder augmentation are presented in Table 8. 
Table 8 Synthetic materials in experimental bladder augmentation

\begin{tabular}{|l|l|l|l|l|}
\hline Year & Author & Animal & Material & Adverse effect \\
\hline 1957 & Kudish [84] & Dogs & Polyvinyl sponges & Foreign body reaction \\
\hline 1970 & Kelâmi et al. [85] & Dogs & $\begin{array}{l}\text { Teflon }{ }^{\circledR} \text { (BARD INC., Murray Hill, } \\
\text { New Jersey, USA) felt }\end{array}$ & $\begin{array}{l}\text { Fibrosis, incomplete urothelial coverage, no smooth } \\
\text { muscle cell growth, graft collapse }\end{array}$ \\
\hline 1994 & Virseda Chamorro et al. [86] & Dogs & $\begin{array}{l}\text { Gore-Tex }{ }^{\circledR} \text { (W.L. GORE and } \\
\text { ASSOCIATES, INC., Flagstaff, } \\
\text { Arizona, USA) }\end{array}$ & No increase in capacity \\
\hline
\end{tabular}

Table 9 Silk scaffolds in experimental bladder augmentation

\begin{tabular}{|c|c|c|c|c|}
\hline Year & Author & Animal & Material & Adverse effect \\
\hline 2013 & Seth et al. [87] & Rat & Silkworm silk scaffold/combined with SIS & Foreign body reaction \\
\hline 2014 & $\begin{array}{l}\text { Chung et al. } \\
{[88]}\end{array}$ & Rat & Silkworm silk fibroin scaffolds combined with SIS & $\begin{array}{l}\text { Bladder stones, bladder rupture, chronic inflamma- } \\
\text { tion, residual silk }\end{array}$ \\
\hline 2015 & Zhao et al. [66] & Rat & $\begin{array}{l}\text { Silkworm silk combined with acellular bladder } \\
\text { matrix graft }\end{array}$ & No increase in capacity \\
\hline 2013 & Tu et al. [89] & Pigs & Acellular silkworm silk scaffolds & Urinary leakage, bladder calculi, graft contraction \\
\hline
\end{tabular}

Polyvinyl sponges [84], Teflon ${ }^{\circledR}$ (BARD INC., Murray Hill, New Jersey, USA; [85]), as well as Gore-Tex ${ }^{\circledR}$ (W.L. GORE and ASSOCIATES, INC., Flagstaff, Arizona, USA); patches [86] have been used in experimental animal studies, too. However, there was no increase in capacity due to the stiffness of the material and no ingrowth of muscle cells [86]. Moreover, foreign body reactions, fibrosis, incomplete urothelial growth as well as no smooth muscle cell ingrowth have been described [84, 85].

Silk-based scaffolds Silk-based scaffolds which have been used in experimental bladder augmentation are shown in Table 9.

To facilitate the growth of urothelial and smooth muscle cells, grafts have been lined with silkworm silk (Bombyx mori). However, Seth et al. described a high incidence of foreign body reaction in either silk matrices or small intestinal submucosa combined with silkworm silk [87]. Chung et al. found regrowth of smooth muscle cells by combining small intestinal submucosa and silkworm silk in a rat cystoplasty model, but again, bladder stones and bladder rupture as well as chronic inflammation and residual silk were present [88]. Zhao et al. used silkworm silk to line a bladder acellular matrix graft in rats. Although there was ingrowth of smooth muscle cells present, bladder stones as well as graft perforation and chronic inflammatory response occurred [66]. Tu et al. tested acellular silkworm silk scaffolds in pigs, and although smooth muscle cells as well as nerve cells and neovascularisation were successful, urinary leakage as well as urinary calculi and graft contraction still ensued [89].

Due to the fact of current inflammation, stone production, leakage and persistence of silk graft remnants, this particular method for bladder augmentation needs to be further investigated. Presumably, a more suitable silk donor has to be found to elim- inate these adverse effects such as antigenicity and formation of calculi.

\section{Conclusion and perspective}

In conclusion, the implementation of tissue and neoorgans fabricated in vitro seems feasible in partial or total organ reconstruction. Seeded biomaterials (collagen, keratin, alginate, acellular tissue matrices, synthetic polymers) surpass non-biomaterials (Teflon ${ }^{\circledR}$ [BARD INC., Murray Hill, New Jersey, USA], silicone, Vicryl ${ }^{\circledR}$ [ETHICON INC., Cincinetti, Ohio, USA], polyvinyl, unseeded collagen matrices) in terms of biocompatibility, degradation, cell adhesion substrate, tissue development, mechanical and physical properties as well as plasticity.

The best results in seeding the grafts are obtained by using autologous urothelial and smooth muscle cells.

Research concerning the use of stem cells, amniotic fluid and progenitor cells from urine as well as "printing" 3D scaffolds in vitro is still ongoing [76, 77, 90].

Minimizing or alleviating the ailments of congenital malformations or traumatic injuries of the urinary tract by operative means remains a challenge for paediatric surgeons as well as for interdisciplinary carers.

New techniques and possibilities in the operating field of bladder augmentation and ureteral reconstruction give new future perspectives in terms of reducing side effects and maximizing the quality of life of the afflicted patients.

Funding Open access funding provided by Medical University of Vienna.

Conflict of interest S. Langer, C. Radtke, E. Györi, A. Springer and M.L. Metzelder declare that they have no competing interests. 
Open Access This article is distributed under the terms of the Creative Commons Attribution 4.0 International License (http://creativecommons.org/licenses/by/4.0/), which permits unrestricted use, distribution, and reproduction in any medium, provided you give appropriate credit to the original author(s) and the source, provide a link to the Creative Commons license, and indicate if changes were made.

\section{References}

1. Lapides J, Diokno AC, Gould FR, Lowe BS. Further observations on self-catheterization. J Urol. 1976;116:169-71.

2. Altaweel W, Jednack R, Bilodeau C, Corcos J. Repeated intradetrusor botulinum toxin type $\mathrm{A}$ in children with neurogenic bladder due to myelomeningocele. J Urol. 2006;175:1102-5.

3. Tudor KI, Sakakibara R, Panicker JN. Neurogenic lower urinary tract dysfunction: evaluation and management. J Neurol. 2016;263:2555-64.

4. Gor RA, Elliott SP. Surgical management of neurogenic lower urinary tract dysfunction. Urol Clin North Am. 2017;44:475-90.

5. Lee B, Featherstone N, Nagappan P, McCarthy L, O'Toole S. British Association of Paediatric Urologists consensus statement on the management of the neuropathic bladder. J Pediatr Urol. 2016;12:76-87. https://doi.org/10.1016/j. jpurol.2016.01.002.

6. Atta CAM, Fiest KM, Frolkis AD, Jette N, Pringsheim T, St Germaine-Smith C, et al. Global birth prevalence of spina bifida by folic acid fortification status: a systematic review and meta-analysis. Am J Public Health. 2016;106:e24-e34.

7. Marks JD, Khoshnood B. Epidemiology of common neurosurgical diseases in the neonate. Neurosurg Clin N Am. 1998;9:63-72.

8. Diamond DA, Chan IHY, Holland AJA, Kurtz MP, Nelson C, Estrada CR, et al. Advances in paediatric urology. Lancet. 2017;390:1061-71.

9. Roberts CJ, Evans KT, Hibbard BM, Laurence KM, Roberts EE, Robertson IB. Diagnostic effectiveness of ultrasound in detection of neural tube defect. The South Wales experience of 2509 scans (1977-1982) in high-risk mothers. Lancet. 1983;2:1068-9.

10. Sturm RM, Cheng EY. The management of the pediatric neurogenic bladder. Curr Bladder Dysfunct Rep. 2016;11:225-33.

11. Nseyo U,Santiago-LastraY.Long-term complications of the neurogenic bladder. UrolClin North Am. 2017;44:355-66.

12. Siffel C, Correa A, Amar E, Bakker MK, Bermejo-Sánchez E, Bianca S, et al. Bladder exstrophy: an epidemiologic study from the International Clearinghouse for Birth Defects Surveillanceand Research, and an overview of theliterature. Am J Med Genet. 2011;157:321-32.

13. 'tHoenL, EcclestoneH, BlokBFM, Karsenty G, PhéV, Bossier $\mathrm{R}$, et al. Long-term effectiveness and complication rates of bladder augmentation in patients with neurogenic bladder dysfunction: a systematic review. Neurourol Urodyn. 2017;36:1685-702.

14. Cuschieri A. Descriptive epidemiology of isolated anal anomalies: a survey of 4.6 million births in europe. Am J Med Genet. 2001;103:207-15.

15. Casey JT, Chan KH, Hasegawa Y, Large T, Judge B, Kaefer $\mathrm{M}$, et al. Long-term follow-up of composite bladder augmentation incorporating stomach in a multi-institutional cohort of patients with cloacal exstrophy. J Pediatr Urol. 2017;13(1):43.e1-43.e6.
16. Lapides J, Diokno AC, Silber SJ, Lowe BS. Clean, intermittent self-catheterization in the treatment of urinary tract disease. J Urol. 1972;107:458-61.

17. De Castro R, Pavanello P, Dòmini R. Indications for bladder augmentation in the exstrophy-epispadias complex. Br J Urol. 1994;73:303-7.

18. Dos Santos J, Lopes RI, Koyle MA. Bladder and bowel dysfunction in children: an update on the diagnosis and treatment of a common, but underdiagnosed pediatric problem. Can Urol Assoc J. 2017;11:64. https:// doi.org/10. 5489/cuaj.4411.

19. Stothers L, Tsang B, Nigro M, Lazare D, Macnab A. An integrative review of standardized clinical evaluation tool utilization in anticholinergic drug trials for neurogenic lower urinary tract dysfunction. Spinal Cord. 2016;54:1114-20.

20. Verpoorten C, Buyse GM. The neurogenic bladder: medical treatment. Pediatr Nephrol. 2008;23:717-25.

21. Apostolidis A, Dasgupta P, Denys P, Elneil S, Fowler CJ, Giannantoni A, et al. Recommendations on the use of botulinum toxin in the treatment of lower urinary tract disorders and pelvic floor dysfunctions: a European consensus report. Eur Urol. 2009;55:100-19.

22. Khan MK, VanderBrinkBA, DeFoorWR, MinevichE, Jackson $\mathrm{E}, \mathrm{Noh} \mathrm{P}$, et al. Botulinum toxin injection in the pediatric population with medically refractory neuropathic bladder. JPediatr Urol. 2016;12:104.e1-104.e6.

23. Groen J, Pannek J, Castro Diaz D, Del Popolo G, Gross T, Hamid R, Karsenty G, Kessler TM, Schneider M, 't Hoen L, Blok B. Summary of European Association of Urology (EAU) guidelines on neuro-urology. Eur Urol. 2016;69:324-33.

24. GearhartJP, Albertsen PC, MarshallFF, Jeffs RD. Pediatric applications of augmentation cystoplasty: the Johns Hopkins experience. JUrol. 1986;136:430-2.

25. Husmann DA. Mortality following augmentation cystoplasty: a transitional urologist's viewpoint. J Pediatr Urol. 2017;13:358-64.

26. Mingin GC, Stock JA, Hanna MK. Gastrocystoplasty: longterm complications in 22 patients. J Urol. 1999;162:1122-5.

27. Biardeau X, Chartier-Kastler E, Rouprêt M, Phé V. Risk of malignancy after augmentation cystoplasty: a systematic review. Neurourol Urodyn. 2016;35:675-82.

28. Boissier R, Di Crocco E, Faure A, Hery G, Delaporte V, Lechevallier E, et al. What is the outcome of paediatric gastrocystoplasty when the patients reach adulthood? BJU Int. 2016;118:980-6.

29. Soergel TM, Cain MP, Misseri R, Gardner TA, Koch MO, Rink RC. Transitional cell carcinoma of the bladder following augmentation cystoplasty for the neuropathic bladder. J Urol. 2004;172(4):1649-52. https://doi.org/10.1097/01. ju.0000140194.87974.56.

30. Esquena Fernández S, Abascal JM, Tremps E, Morote J. Gastric cancer in augmentation gastrocystoplasty. Urol Int. 2005;74:368-70.

31. Kälble T, Hofmann I, ThüroffJW, Stein R, Hautmann R, Riedmiller $\mathrm{H}$, et al. Sekundärmalignome in Harnableitungen. Urologe. 2012;51:500-6.

32. KispalZF, Kardos D, JillingT, Kereskai L, Isaacs M, Balogh DL, et al. Long-term histological and mucin alterations in the neobladder mucosa following urinary bladder augmentation or substitution with gastrointestinal segment. J Pediatr Urol. 2015;11:349.e1-349.e6.

33. Kono Y, Terada N, Takashima Y, Hikami K, Hida T, Goto $\mathrm{S}$, et al. Advanced adenocarcinoma of the bladder after augmentation gastrocystoplasty. Hinyokika Kiyo. 2016;62:33-7.

34. Greenwell TJ, Venn SN, Mundy AR. Augmentation cystoplasty. BJU Int. 2001;88:511-25. 
35. OdehRI, FarhatWA, PennaFJ, KoyleMA, LeeLC, ButtH, etal. Outcomes of seromuscular bladder augmentation versus standard ileocystoplasty: a single institution experience over 14 years. JPediatr Urol. 2017;13:200.e1-200.e5.

36. Escudero RM, Patiño GE, FernándezER, Gil MJC, García EL, Alonso AH, et al. Bladder augmentation using the gastrointestinal tract. Indication, follow up and complications. Arch Esp Urol. 2011;64:953-9.

37. Schlomer BJ, Copp HL. Cumulative incidence of outcomes and urologic procedures after augmentation cystoplasty. JPediatr Urol. 2014;10:1043-50.

38. Metcalfe PD, Cain MP, Kaefer M, Gilley DA, Meldrum KK, Misseri R, et al. What is the need for additional bladder surgery after bladder augmentation in childhood? J Urol. 2006;176:1801-5.

39. Gough DC. Enterocystoplasty. BJU Int. 2001;88:739-43.

40. Murray K, Nurse DE, Mundy AR. Secreto-motor function of intestinal segments used in lower urinary tract reconstruction. BrJ Urol. 1987;60:532-5.

41. Neuhof H. Fascial transplantation into visceral defects: an experimental and clinical study. Surg Gynecol Obstet. 1917;25:383-92.

42. Manzoni C, Grottesi A, D’Urzo C, Pintus C, Fadda G, Perrelli L.Anoriginal technique for bladder autoaugmentation with protective abdominal rectus muscle flaps: an experimental study in rats. JSurg Res. 2001;99:169-74.

43. Weingarten JL, Cromie WJ, Paty RJ. Augmentation myoperitoneocystoplasty. J Urol. 1990;144:156-8.

44. Oesch I. Neourothelium in bladder augmentation. An experimental study in rats. Eur Urol. 1988;14:328-9.

45. Motley RC, Montgomery BT, Zollman PE, Holley KE, Kramer SA. Augmentation cystoplasty utilizing de-epithelialized sigmoid colon: a preliminary study. J Urol. 1990;143:1257-60.

46. Niku SD, Scherz HC, Stein PC, Parsons CL. Intestinal deepithelialization and augmentation cystoplasty: an animal model. Urology. 1995;46:36-9.

47. Clementson Kockum C, Willén R, Malmfors G. Bladder augmentation with different forms of intestinal grafts: an experimental study in the pig. BJU Int. 1999;83(3):305-11.

48. Burgu B, Gökce Mİ, Aydoğdu Ö, Süer E, Kankaya D, Soygür T. Combining gastric and ileal segments, does it overcome segment-related complications? An experimental study on rats. Urol Res. 2011;39:39-44.

49. Thangappan R, Eandi JA, Modi J, KurzrockEA. Epitheliumfree bladder wall graft: epithelial Ingrowth and regeneration-clinical implications for partial cystectomy. J Urol. 2012;187:1450-7.

50. Yamataka A, Wang K, Okada Y, Kobayashi H, Lane GJ, Yanai $\mathrm{T}$, et al. Living-related partial bladder transplantation for bladder augmentation in rats: an experimental study. JPediatr Surg. 2003;38:913-5.

51. Ikeguchi EF, Stifleman MD, Hensle TW. Ureteral tissue expansionforbladderaugmentation. JUrol. 1998;159:1665-8.

52. Cranidis A, Nestoridis G, Delakas D, Lumbakis P, Kanavaros P. Bladder autoaugmentation in the rabbit using de-epithelialized segments of small intestine, stomach and lyophilized human dura mater. BrJ Urol. 1998;81:62-7.

53. Aslan A, Akkaya B, Karagüzel G, Karpuzoglu G, Melikoglu M. Bladder augmentation with an omental pedicled gastric seromuscular flap without thenecessity of gastric resection. Urol Res. 2004;32:298-303.

54. Close CE, Anderson PD, Edwards GA, Mitchell ME, Dewan PA. Autoaugmentation gastrocystoplasty: further studies of the sheep model. BJU Int. 2004;94:658-62.
55. Dapena L, Dapena I, Regadera J, Gaspar MJ, GonzálezPeramato P. Histerocystoplasty: a novel surgical procedure in the rat. J Surg Res. 2012;175:157-62.

56. Dapena L, Dapena I, Regadera J, Silva-Mato A, GonzálezPeramato P. Bladder autoaugmentation with protective autologous uterine flap. Experimental study in the rat. Int $\mathrm{J}$ Surg. 2013;11:270-4.

57. Kotecha R, Toledo-Pereyra LH. Hysterocystoplasty: a new surgical technique for bladder reconstruction. J Surg Res. 2012;176:397-9.

58. Barski D, Gerullis H, Ecke T, Yang J, Varga G, Boros M, et al. Bladder reconstruction with human amniotic membrane in a xenograft rat model: a preclinical study. Int J Med Sci. 2017;14:310-8.

59. Blanco Bruned JL, Alvarez Díaz JF, Sáez López A, Oliver Llinares F, Prado Fernández C, González Landa G. Seromuscular colocystoplasty lined by urothelium. Experimental study in rats. Cir Pediatr. 2001;14:162-7.

60. HafezAT, Afshar K, BägliDJ, BahoricA, Aitken K, Smith CR, et al. Aerosol transfer ofbladder urothelial and smooth muscle cells onto demucosalized colonic segments for porcine bladder augmentation in vivo: a 6-week experimental study. J Urol. 2005;174(4):1663-8.

61. Hidas G, Lee HJ, Bahoric A, Kelly MS, Watts B, Liu Z, et al. Aerosol transfer of bladder urothelial and smooth muscle cells onto demucosalized colonic segments for bladder augmentation: In vivo, long term, and functional pilot study. J Pediatr Urol. 2015;11:260.e1-260.e6.

62. Fraser M, Thomas DF, Pitt E, Harnden P, Trejdosiewicz LK, Southgate J.A surgical model of composite cystoplasty with cultured urothelial cells: a controlled study of gross outcome and urothelial phenotype. BJU Int. 2004;93:609-16.

63. Turner A, Subramanian R, Thomas DFM, Hinley J, Abbas SK, Stahlschmidt J, et al. Transplantation of autologous differentiated urothelium in an experimental model of composite cystoplasty. Eur Urol. 2011;59:447-54.

64. Schaefer BM, Lorenz C, Back W, Moll R, Sun TT, Schober $\mathrm{C}$, et al. Autologous transplantation of urothelium into demucosalized gastrointestinal segments: evidence for epithelialization and differentiation of in vitro expanded and transplanted urothelial cells. J Urol. 1998;159:284-90.

65. Hafez AT, Bägli DJ, Bahoric A, Aitken K, Smith CR, Herz D, et al. Aerosol transfer of bladder urothelial and smooth muscle cells onto demucosalized colonic segments: a pilot study. J Urol. 2003;169:2316-20.

66. Zhao Y, He Y, Guo J, Wu J, Zhou Z, Zhang M, et al. Time-dependent bladder tissue regeneration using bilayer bladder acellular matrix graft-silk fibroin scaffolds in a rat bladder augmentation model. Acta Biomater. 2015;23:91-102.

67. Probst M, Piechota HJ, Dahiya R, Tanagho EA. Homologous bladder augmentation in dog with the bladder acellular matrix graft. BJU Int. 2000;85:362-71.

68. Wefer J, Sievert KD, Schlote N, Wefer AE, Nunes L, Dahiya $\mathrm{R}$, et al. Time dependent smooth muscle regeneration and maturation in a bladder acellular matrix graft: histological studies and in vivo functional evaluation. J Urol. 2001;165:1755-9.

69. Falke G, Caffaratti J, Atala A. Tissue engineering of the bladder. World J Urol. 2000;18:36-43.

70. Cayan S, Chermansky C, Schlote N, Sekido N, Nunes L, Dahiya R, et al. The bladder acellular matrix graft in a rat chemical cystitis model: functional and histologic evaluation. JUrol. 2002;168:798-804.

71. Kropp BP, Eppley BL, Prevel CD, Rippy MK, Harruff RC, Badylak SF, et al. Experimental assessment of small intestinal submucosa as a bladder wall substitute. Urology. 1995;46:396-400. 
72. Parshotam Kumar G, Barker A, Ahmed S, Gerath J, Orford J. Urinary bladder auto augmentation using INTEGRA ${ }^{\circledR}$ and SURGISIS ${ }^{\circledR}$ : an experimental model. Pediatr Surg Int. 2010;26:275-80.

73. Sharma AK, Bury MI, Marks AJ, Fuller NJ, Meisner JW, Tapaskar N, et al. A nonhuman primate model for urinary bladder regeneration using autologous sources of bone marrow-derived mesenchymal stem cells. Stem Cells. 2011;29:241-50.

74. Talab SS, Kajbafzadeh A-M, Elmi A, Tourchi A, Sabetkish S, Sabetkish N, et al. Bladder reconstruction using scaffoldless autologous smoothmuscle cell sheet engineering: early histological outcomes for autoaugmentation cystoplasty. BJU Int. 2014;114:937-45.

75. Zhe Z, Jun D, Yang Z, Mingxi X, Ke Z, Ming Z, et al. Bladder acellular matrix grafts seeded with adipose-derived stem cells and incubated intraperitoneally promote the regeneration of bladder smooth muscle and nerve in a rat model of bladder augmentation. Stem Cells Dev. 2016;25:405-14.

76. Atala A. Tissue engineering of human bladder. Br Med Bull. 2011;97:81-104.

77. Yoo JJ, Olson J, Atala A, Kim B. Regenerative medicine strategies for treating neurogenic bladder. Int Neurourol J. 2011;15:109-19.

78. Subramaniam R, Hinley J, Stahlschmidt J, Southgate J. Tissue engineering potential of urothelial cells from diseased bladders. J Urol. 2011;186:2014-20.

79. Pattison M, Webster TJ, Leslie J, Kaefer M, Haberstroh KM. Evaluating the in vitro and in vivo efficacy of nanostructured polymers for bladder tissue replacement applications. Macromol Biosci. 2007;7:690-700.

80. Kwon TG, Yoo JJ, Atala A. Local and systemic effects of a tissue engineered neobladder in a canine cystoplasty model. JUrol. 2008;179:2035-41.

81. Zhou L, Yang B, Sun C, Qiu X, Sun Z, Chen Y, et al. Coadministration of platelet-derived growth factor-BB and vascular endothelial growth factor with bladder acellular matrix en- hances smooth muscle regeneration and vascularization for bladder augmentation in a rabbit model. Tissue Eng PartA. 2013;19:264-76.

82. Vardar E, Larsson HM, Engelhardt EM, Pinnagoda K, Briquez PS, Hubbell JA, et al. IGF-1-containing multilayered collagen-fibrin hybrid scaffolds for bladder tissue engineering. Acta Biomater. 2016;41:75-85.

83. Leonhäuser D, Stollenwerk K, Seifarth V, Zraik IM, Vogt M, Srinivasan PK, et al. Two differentially structured collagen scaffolds for potential urinarybladder augmentation: proof of concept study in a Göttingen minipig model. J Transl Med. 2017;15:3.

84. Kudish HG. The use of polyvinyl sponge for experimental cystoplasty. J Urol. 1957;78:232-5.

85. Kelâmi A, Dustmann HO, Lüdtke-Handjery A, Cárcamo V, Herlld G. Experimental investigations of bladder regeneration using teflon-felt as a bladder wall substitute. J Urol. 1970;104:693-8.

86. Virseda Chamorro M, González Meli B, Salinas Casado J, Mellado F, Galán Torres JA, García Marcos J, et al. Experimentalbladderaugmentation with Gore-texamine: biomechanical, biochemical and biostructural aspects. Arch Esp Urol. 1994;47:958-66.

87. Seth A, ChungYG, GilES, Tu D, FranckD, Di Vizio D, etal. The performance of silkscaffoldsinaratmodel of augmentation cystoplasty. Biomaterials. 2013;34:4758-65.

88. Chung YG, Algarrahi K, Franck D, Tu DD, Adam RM, Kaplan DL, et al. The use of bi-layer silk fibroin scaffolds and small intestinal submucosa matrices to support bladder tissue regeneration in a rat model of spinal cord injury. Biomaterials. 2014;35:7452-9.

89. Tu DD, Chung YG, Gil ES, Seth A, Franck D, Cristofaro V, et al. Bladder tissue regeneration using acellular bi-layer silk scaffolds in a large animal model of augmentation cystoplasty. Biomaterials. 2013;34:8681-9.

90. Garriboli M, Radford A, Southgate J. Regenerative medicine in urology. Eur J Pediatr Surg. 2014;24:227-36. 